\title{
InfoNorth
}

\section{Energy Constraints on Incubating Common Eiders in the Canadian Arctic (East Bay, Southampton Island, Nunavut)}

\author{
By Grace E. Bottitta
}

I N 1994, I began to search for fieldwork in Alaska, but found it difficult having worked exclusively in temperate climates. I took a chance and moved north. Fortunately, I attained employment within the first few days of my arrival in April 1995. I took my first steps on the tundra within the Prudhoe Bay oilfield, monitoring bird activity and locating nests for Troy Ecological Research Associates. During my first Arctic summer, I observed birds in glorious breeding plumage and demonstrating nesting behaviours, arctic fox (Alopex lapogus), and herds of caribou (Rangifer tarandus-granti). Dehydration, sore ankles from trudging across soggy tundra in hip waders, fields of wild flowers, tundra naps, swarms of mosquitoes, unlimited sunshine, and cutting cold winds were common occurrences. Towards the end of the season, my duties expanded to include searching for waterfowl nests and radio-tracking female spectacled eiders (Somateria fischeri). Although I returned to the same area the following season, my primary duties shifted to eider work, with sporadic walks on the tundra thrown in.

From spring 1997 until early 1998, I worked for the United States Geological Service/Biological Resources Division (USGS/BRD) in Alaska on a series of projects. The first, for Dr. Paul Flint of the Alaska Biological Science Center, USGS/BRD, was a spectacled eider project located on the Yukon-Kuskokwim Delta. I then traveled onwards to Cold Bay, Alaska, to band molting Steller's eiders (Polysticta stelleri) and to Baja California, Mexico, to study black brant (Branta bernicla nigricans) and their wintering habits.

During this period, I became interested in pursuing a graduate degree and was introduced to a mentoring program created by the Women in Ornithology Group (WORG). The program matched my interests in shorebirds and waterfowl with Professor Erica Nol from Trent University. I corresponded with Professor Nol a few times during my 1997 field season, and she introduced me to Grant Gilchrist of the Canadian Wildlife Service (CWS). Dr. Gilchrist had recently begun researching common eider ducks (Somateria mollissima) in the eastern Canadian Arctic at East Bay, Southampton Island. The nesting eiders I had worked on previously were primarily solitary

nesters, with nests often spaced $100 \mathrm{~m}$ apart. In contrast, the 4500 common eider nests at the East Bay colony are often less than $5 \mathrm{~m}$ apart. Since the project's start in 1996, the CWS had established a small tent camp and five observation blinds. These blinds permit behavioural observations without disturbing incubating eiders or their avian predators. Dr. Gilchrist was searching for graduate students to study detailed aspects of eider ecology. My project at the East Bay colony, which encompassed the 1998 and 1999 field seasons, examined the influence of female eider energy reserves on reproductive success. In September 1998, I began my M.Sc. program at Trent University in Peterborough, Ontario, where I am co-supervised by Professor Nol and Dr. Gilchrist.

\section{CONSERVATION CONCERNS OF CIRCUMPOLAR EIDER DUCK POPULATIONS}

Common eider ducks have a circumpolar distribution. Several populations that occur in polar areas during the summer move to northern or temperate coastal areas during winter. All eider species have delayed reproductive maturity, low rates of recruitment, and high rates of adult survival (often $15+$ years). These characteristics, coupled with their gregarious nature, render eider ducks highly vulnerable to the effects of hunting, lead poisoning, contaminants, and oil pollution. Even slight reductions in adult survival rates can cause populations to decline. Low annual rates of recruitment and successive years of reproductive failure can also affect populations and slow their recovery. Little is known about the population dynamics of eider ducks, although recent surveys suggest that dramatic population declines have occurred with some populations in Canada and Greenland (e.g., Boertmann and Mosbech, 1996; Dickson et al., 1997; Suydam et al., 1997; Robertson and Gilchrist, 1998).

Concern within the scientific community has recently generated several conservation policy documents. These include the Circumpolar Eider Conservation Strategy and Action Plan of the Circumpolar Seabird Working Group (Bart, 1997), the Seaduck Joint Venture (revised North 
American Waterfowl Management Plan, 1999), and the Cooperative Research Strategy for Eider Ducks Breeding in Northern Canada of the Canadian Wildlife Service (Gilchrist and Dickson, 1999). All of these documents stress the need for research and monitoring of eider ducks.

Information regarding the population dynamics of common eiders breeding in the Canadian Arctic is limited and out of date (Reed and Erskine, 1986). The CWS East Bay project was established to research these issues. Research topics at the colony include predator-prey interactions, the influence of ice cover and snowmelt on nest initiation, levels of heavy metal contamination and internal parasite loads, population ecology (e.g., adult survival rates), and sources of annual variation in reproductive success.

A key component of eider reproductive ecology is the influence of body reserves on reproduction (Thompson and Raveling, 1987). Energy reserves are particularly important for eiders nesting in the Arctic, where short breeding seasons and extreme environmental conditions there can constrain the ability of eiders to establish the energy reserves necessary for egg laying, fasting during incubation (24 days), and subsequent brood rearing (Erikstad et al., 1993). My individual project examines the costs of incubation among arctic common eiders: specifically, how variation in energy reserves and annual environmental conditions (e.g., temperature, precipitation) influence female incubation behaviour and reproductive success.

\section{GENERAL THEORY}

Among birds, there may be a trade-off between longterm survival and immediate reproductive success. Waterfowl may respond to their energetic state by adjusting their nest attendance behaviour to avoid starvation or dehydration. For example, long-lived waterfowl may abandon their nests if energy reserves reach levels that threaten immediate or long-term survival, so that future fecundity and survival are rarely sacrificed for immediate reproductive success (Tombre and Erikstad, 1996). These issues may be particularly important among waterfowl species that fast during the breeding season and rely on energy reserves for egg production, incubation, and duckling care (Erikstad et al., 1993).

Inter- and intraspecific analyses of incubating waterfowl demonstrate a positive relationship between nest attentiveness and body mass (Afton and Paulus, 1992; Yerkes, 1998). For example, a decline in nest attendance occurs among geese with low energy reserves. Low nest attentiveness results in high nest predation and slows egg development (Alrich and Raveling, 1983; Tombre and Erikstad, 1996). Female common eiders nesting in the Arctic are ideal for examining trade-offs between adult survival (mediated by energy reserves) and reproduction. These female common eiders have an incubation constancy of $96.3 \%$ (daily rate) for approximately 24 days,

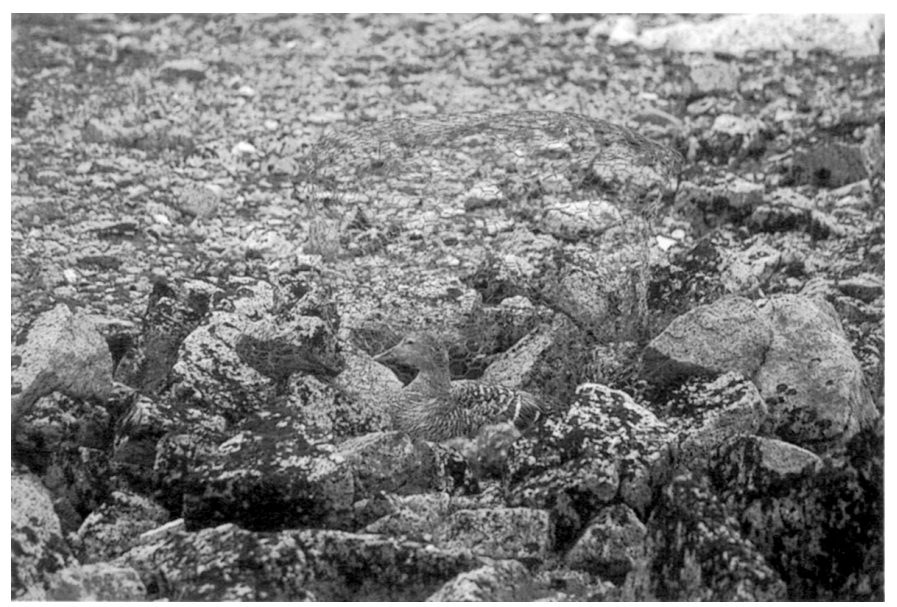

Female common eider incubating her nest within a funnel trap. Photo by Grace E. Bottitta.

one of the highest rates found in ducks (Afton and Paulus, 1992). They rely on fat and muscle reserves accrued prior to laying (Parker and Holm, 1990), and their weight loss during incubation is often $40 \%$ of their gross pre-incubation body weight (Gorman and Milne, 1972). Severe winters, late ice breakup, and long migrations may decrease their ability to build up reserves sufficient for reproduction.

\section{FIELD SITE}

Mitivik Island, East Bay, Southampton Island, Nunavut $\left(64^{\circ} 02^{\prime} \mathrm{N}, 81^{\circ} 47^{\prime} \mathrm{W}\right)$, supports one of the highest densities of breeding common eiders in the Canadian Arctic (Abraham and Ankney, 1986). The colony, located on a low-lying island approximately $800 \mathrm{~m}$ long and $200 \mathrm{~m}$ wide, annually supports approximately 4500 common eider nests. It also supports breeding Canada geese (Branta canadensis), brant (Branta bernicla), red-throated loons (Gavia stellata), snow buntings (Plectrophenax nivalis), black guillemots (Cepphus grylle), herring gulls (Larus argentatus), and king eiders (Somateria spectabilis), as well as the occasional hungry polar bear. The island is covered by granite rocks with small patches of tundra and scattered with 12 small freshwater ponds. All but three of these ponds evaporate when not supplied by rain throughout the summer.

Over 1500 common eiders have been banded at the East Bay colony since 1996. Males and pre-incubating females are trapped using a seine net $(100 \mathrm{~m}$ long by $4 \mathrm{~m}$ tall) in June of each season. Captured birds are measured, weighed, and banded with an individual colour/alphanumeric combination as well as a metal United States Fish and Wildlife Service band. A small sample of incubating hens has been captured on the nest using mist nets, bownet traps (Weller, 1957; Salyer, 1962), chicken wire funnel traps, and noose poles. The latter two methods were the most successful. 


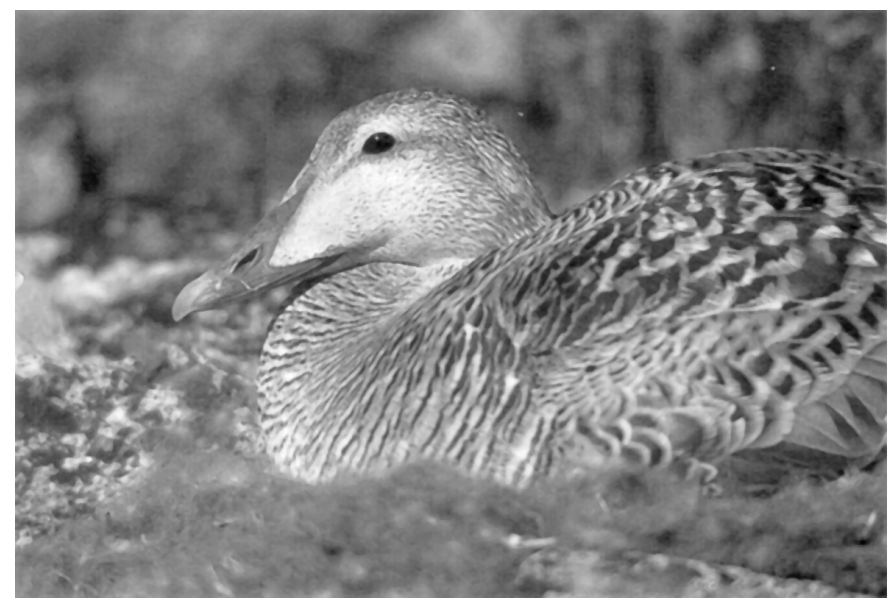

Incubating common eider female. Photo by Grant Gilchrist, CWS.

\section{PROJECT ORIGIN, DESIGN, AND IMPLEMENTATION}

My research design is similar to Tombre and Erikstad's (1996) experimental study of incubation effort in High Arctic barnacle geese (Branta leucopsis). They examined the cost of reproduction by manipulating the length of the incubation period. The body condition and behaviour of experimental and control hens were compared, particularly during the critical last five days of the incubation period.

In order to determine the influence of body condition on incubation behaviour and nest outcome, I manipulated clutch ages in June through August of 1998 and 1999. During incubation (exclusively by females), clutches were switched pairwise between nests to shorten or prolong the length of incubation by an average of five days (1998, $\mathrm{n}=$ $30 ; 1999, \mathrm{n}=40$ ). In addition, I monitored the behaviour and reproductive success of unmanipulated control hens $(1998, \mathrm{n}=182 ; 1999, \mathrm{n}=180)$.

I predicted that hens with incubation periods extended by five days would have a lower body condition at the end of incubation than females with shortened or unmanipulated incubation. This lower body condition would cause hens to (1) take more incubation breaks (to drink or eat), (2) take longer breaks than the population mean, (3) defend nests weakly from predator attack, (4) experience a higher nest predation rate (associated with an increase of time spent off the nest), and (5) abandon the nest more frequently (to avoid starvation or dehydration).

Body condition at beginning of incubation affects nest attendance, nest abandonment, and depredation. Incubating eiders rely solely on their energy reserves, and those possessing a "good" body condition should not need to take frequent or lengthy incubation breaks (Ankney and MacInnes, 1978; Yerkes, 1998). Inversely, females in poor condition early in incubation should take frequent and/or longer breaks (perhaps to drink or eat). I predicted that common eider hens with low energy reserves prior to

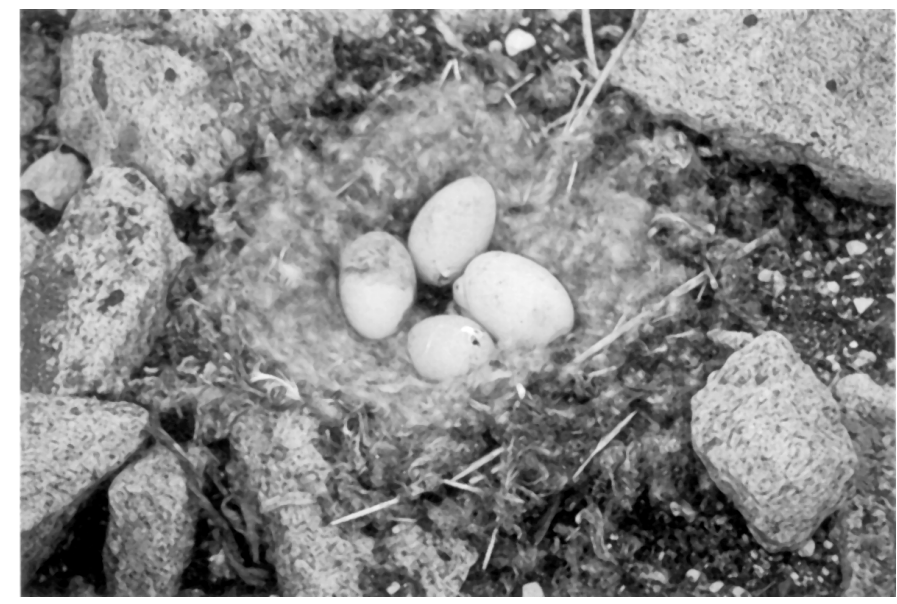

A RIMS within an active common eider nest. Photo by Grace E. Bottitta.

incubation would be less likely to incubate their clutch to hatch than hens in good condition at laying.

Incubating females in a sample group were weighed one to three times during various stages of incubation to determine their individual rate of mass loss $(1998, n=40$; $1999, \mathrm{n}=69$ ). Body condition was inferred from body mass and controlled for body size (Summers, 1988; Gloutney and Clark, 1991; Tombre and Erikstad, 1996). This method allowed me to compare hens using body condition as an index. Manipulated (1998, $\mathrm{n}=36,1999$, $\mathrm{n}=30)$ and control females $(1998, \mathrm{n}=182 ; 1999, \mathrm{n}=180+)$ were also observed during the incubation period to compare nest attendance patterns. The length and frequency of incubation breaks were monitored in three ways: (1) by daily behavioural observations ( $3-6$ hours) from blinds in 1998 and 1999; (2) during several continuous 24 hour (1998 and 1999) and 48 hour (1999 only) behavioural watches; and (3) by Remote Incubation Monitoring Systems (RIMS) placed in individual nests (1999 only, $\mathrm{n}=39$ ).

Behavioural observations were conducted from blinds overlooking study plots. Data collected included (1) total time (min.) hen was off nest per observation period; (2) mean recess length (time off nest); (3) number of recesses per observation period; (4) distance, activity, and location of incubation breaks; and (5) number, activity, and outcome of predator interactions within the plots.

The RIMS permitted me to monitor nest attendance continuously and remotely. The devices consisted of a pressure-sensitive microswitch covered by half an artificial egg. Data on the activity of the hen on the nest were transmitted to a receiver and then downloaded onto a laptop computer. Most RIMS were placed in the nest early in the incubation period and removed during or after hatch. I also carried out behavioural observations of RIMS nests to confirm that the RIMS-generated data were accurate.

Climatic conditions as well as early season ice cover in East Bay may also contribute to the variation of nest initiation date and affect length of incubation period, nest success, early season body condition, and mass loss of 


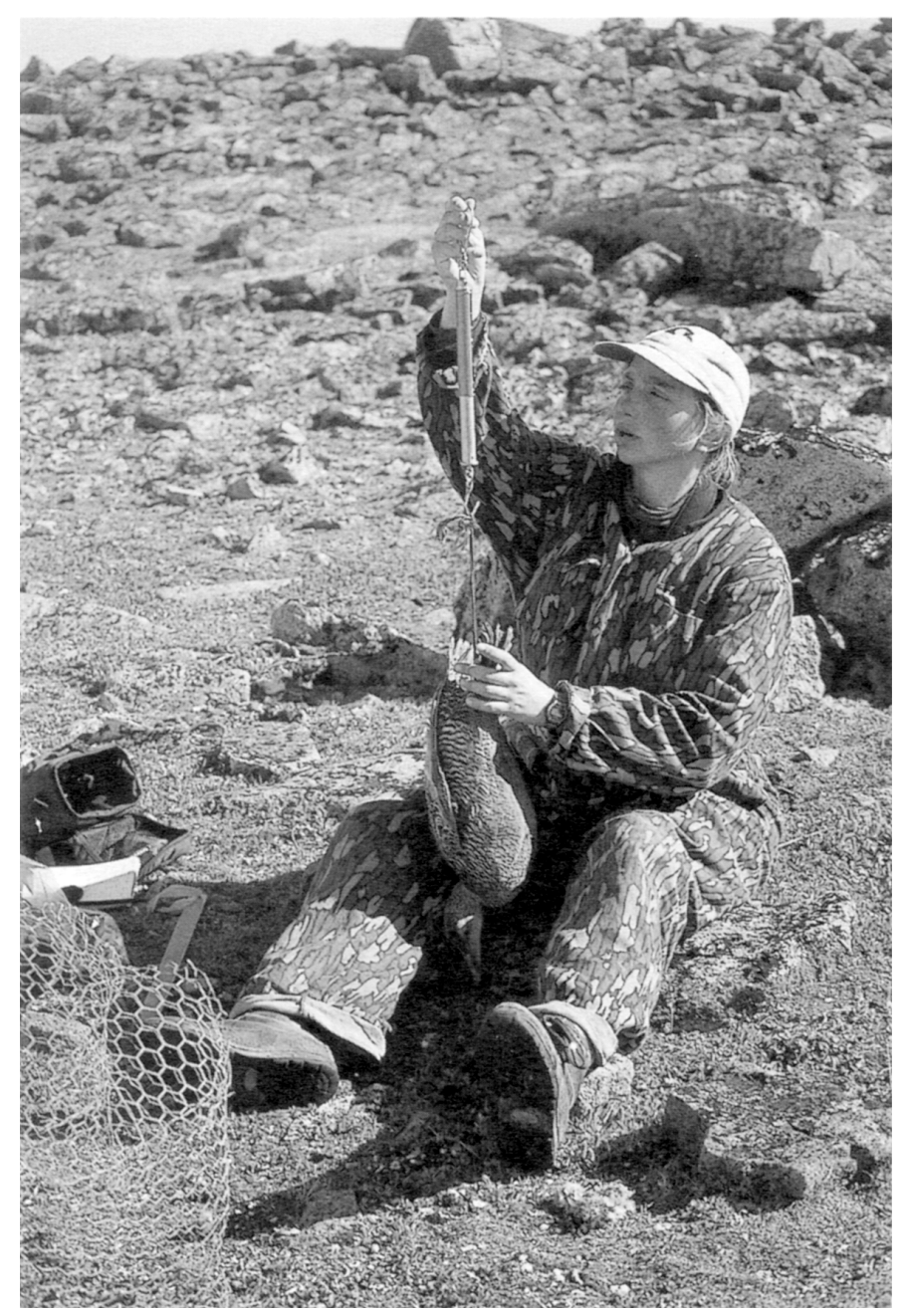

Grace Bottitta measuring the body mass of a common eider female. Photo by Erin Stephens.

incubating female eiders. Information on climatic conditions was recorded daily in camp by a Weatherlink weather station. The weather during the 1999 season was drastically different from that experienced in 1998. In 1998 sunshine was frequent, which was great for camp morale, but not for thirsty birds. All but two of the island's 13 shallow drinking holes evaporated by mid-July. In contrast, the summer of 1999 was wet and cold (even by Arctic standards). Ponds did not dry up, and hens moved off their nests less frequently.

\section{PRELIMINARY RESULTS}

Informal interpretation of the RIMS data indicated that the majority of incubation recesses occurred during the hour before sunset and the hour just after sunset. Recess breaks ranged from 3 to 90 minutes. As predicted, almost all predation by herring gulls and parasitic jaegers (Stercorarius parasiticus) occurred when the hens were taking recess breaks from their nests. This indicates that there is a clear cost to incubation recesses. Other preliminary results include an obvious nonlinear trend in the decrease of body mass throughout incubation in both the 1998 and 1999 seasons. As has been observed at other eider colonies, body mass is lost quickly within the first 15 days of incubation, then levels off (Hario, 1983).

The clutch manipulations helped to determine the correlation between physiological condition and incubation behaviours of incubating females and their nest outcome. As predicted, females with shortened incubation experienced the highest nest success (including protection from predators and incubation breaks/recesses). Extended-incubation females had a lower body condition and demonstrated a greater tendency to abandon the nest in the final days before hatch than either shortened-incubation or control hens. The combination of a hen's level of energy reserves and behavioural observations indicated that abandonment during the late stages of incubation was caused either by starvation or by the inability of the hen in poor body condition to cope with persistent predator attack. As expected, the length of incubation recesses increased for extended-incubation females during the last five days before hatch.

Information from this project has generated the first experimental and behavioural data on how variation of energy reserves influences annual fecundity of the common eider in the Canadian Arctic. These data will provide baseline information for long-term population monitoring at East Bay. They also provide the opportunity to compare reproductive characteristics of common eiders in northern Hudson Bay with those of other eider duck populations around the world.

\section{ACKNOWLEDGEMENTS}

I am honoured to be the recipient of the 1999 Jennifer Robinson Memorial Scholarship from the Arctic Institute of North America. I also received funding from the following: Arctic Institute of North America Grants in Aid, the Canadian Wildlife Service - Northern Conservation Division, the John K. Cooper Foundation, the Society of Canadian Ornithologists (the Taverner Award), and Trent University. The Polar Continental Shelf Project and the Nunavut Research Institute in Iqaluit provided logistical support. The Hunters and Trappers Association of Coral Harbour, as well as the community of Coral Harbour, provided project support. Life in camp would not have been as pleasant without Lynda Porter of the Nunavut Research Institute in Iqaluit and the 1998 and 1999 CWS East Bay field crews: Erin Stephens, Mitch Meredith, Ian "the Scot" Stenhouse, Karen Truman, Karel "Gull Boy" Allard, Cindy Anderson, Terry Armstrong, Josiah Nakoolak, Thomas Alogut, Bill "Oatmeal Man" Barrow, Mark Wayland, and Grant Gilchrist. Maureen Kay assisted from Yellowknife with logistical planning. A special thanks to Mitch and Erin, who supplied extra encouragement, suggestions, and enthusiasm and weren't afraid to crawl across the island. I am indebted to $\mathrm{Al} \mathrm{Kift,} \mathrm{the} \mathrm{electronics}$ guru of Trent University, for creating the RIMS and introducing me to the technology. I am grateful to Dr. Grant Gilchrist for the 
opportunity to take part in the East Bay eider project; both he and Erica Nol provided unlimited patience and guidance.

\section{REFERENCES}

ABRAHAM, K.F., and ANKNEY, C.D. 1986. Summer birds of East Bay, Southampton Island, Northwest Territories. Canadian Field-Naturalist 100:180-185.

AFTON, A.D., and PAULUS, S.L. 1992. Incubation and brood care. In: Batt, B.D.J., Afton, A.D., Anderson, M.G., Ankney, C.D., Johnson, D.H., Kadlec, J.A., and Krapu, G.L., eds. Ecology and management of breeding waterfowl. Minneapolis: University of Minnesota Press. 30-61.

ALRICH, T.E., and RAVELING, D.G. 1983. Effects of experience and body weight on incubation behavior of Canada Geese. Auk 100:670-679.

ANKNEY, C.D., and MacINNES, C.D. 1978. Nutrient reserves and reproductive performance of female lesser snow geese. Auk 95:459-471.

BART, J. 1997. Circumpolar Eider Conservation Strategy and Action Plan. Circumpolar Seabird Working Group, Conservation of Arctic Flora and Fauna. Available from CAFF International Secretariat, Hafnastraeti 97, 600 Akureyri, Iceland.

BOERTMANN, D., and MOSBECH, A. 1996. Seabird colonies in western Greenland. Technical Report from the National Environmental Research Institute, Denmark.

DICKSON, D.L., COTTER, R.C., HINES, J.E., and KAY, M.F. 1997. Distribution and abundance of king eiders Somateria spectabilis in the western Canadian Arctic. In: Dickson, D.L., ed. King and common eiders of the western Canadian Arctic. Canadian Wildlife Service Occasional Paper No. 94. Ottawa: Minister of Supply and Services Canada. 29-39.

ERIKSTAD, K.E., BUSTNES, J.O., and MOURN, T. 1993. Clutch-size determination in precocial birds: A study of the common eider. Auk 110:623-629.

GILCHRIST, H.G., and DICKSON, L. 1999. A cooperative research strategy for king and common eider ducks breeding in northern Canada. Unpublished report. Available at Canadian Wildlife Service, Environment Canada, Suite 301, 5204-50th Avenue, Yellowknife, Northwest Territories X1A 1E2, Canada.
GLOUTNEY, M.L., and CLARK, R.G. 1991. The significance of body mass to female dabbling ducks during late incubation. Condor 93:811-816.

GORMAN, M.L., and MILNE, H. 1972. Creche behaviour in the common eider, S. m. mollissima. Ornis Scandinavica 3:21-26.

HARIO, M. 1983. Weight loss of incubating female eiders. Suomen Riista 30:28-33.

PARKER, H., and HOLM, H. 1990. Patterns of nutrient and energy expenditure in female common eiders nesting in the High Arctic. Auk 107:660-668.

REED, A., and ERSKINE, A.J. 1986. Populations of common eider in eastern North America: Their size and status. In: Reed, A., ed. Eider ducks in Canada. Canadian Wildlife Service, Report Series 47:156-162.

ROBERTSON, G.J., and GILCHRIST, H.G. 1998. Evidence of population declines among common eiders breeding in the Belcher Islands. Arctic 51:378-385.

SALYER, J.W. 1962. A bow-net trap for ducks. Journal of Wildlife Management 26:219-221.

SUMMERS, R.W. 1988. The use of linear measurements when comparing masses. Bird Study 1988:77-79.

SUYDAM, R.S., QUAKENBUSH, L.T., JOHNSON, M., GEORGE, J.C., and YOUNG, J. 1997. Migration of king and common eiders past Point Barrow, Alaska during spring 1987, spring 1994, summer/fall, 1994. In: Dickson, D.L., ed. King and common eiders of the western Canadian Arctic. Canadian Wildlife Service Occasional Paper No. 94. Ottawa: Minister of Supply and Services Canada. 21-28.

THOMPSON, S., and RAVELING, D.G. 1987. Incubation behavior of emperor geese compared with other geese: Interactions of predation, body size and energetics. Auk 104:707-716.

TOMBRE, I.M., and ERIKSTAD, K.E. 1996. An experimental study of incubation effort in high-Arctic barnacle geese. Journal of Animal Ecology 65:325-331.

WELLER, M.W. 1957. An automatic nest trap for waterfowl. Journal of Wildlife Management 21:456-458.

YERKES, T. 1998. The influence of female age, body mass, and ambient conditions on redhead incubation constancy. Condor 100:62-68.

Grace E. Bottitta is the 1999 recipient of the Jennifer Robinson Scholarship. She is currently a Master of Science candidate in the Watershed Ecosystems Graduate Program at Trent University in Peterborough, Ontario. 